REVISTA de

PEDAGOGIE
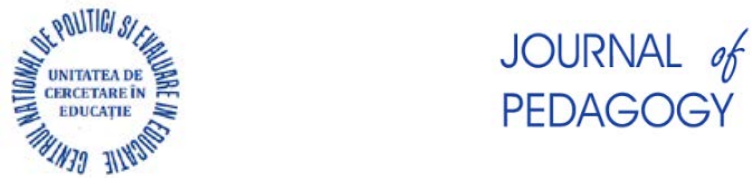

http://revped.ise.ro

Print ISSN 0034-8678; Online ISSN: 2559 - 639X

\title{
LOW QUALITY OF THE EDUCATIONAL PROCESS - MAIN CAUSE OF THE EARLY SCHOOL LEAVING
}

Slaba calitate a procesului educaţional - cauza principală a părăsirii timpurii a şcolii

\section{Adela Mihaela ŢĂRANU}

\author{
Journal of Pedagogy, 2020 (1), 31 - 50 \\ https://doi.org/10.26755/RevPed/2020.1/31
}

The online version of this article can be found at: http://revped.ise.ro/category/2020/

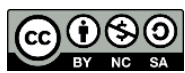

This work is licensed under the Creative Commons Attribution-NonCommercial-ShareAlike 4.0 International License.

To view a copy of this license, visit http://creativecommons.org/licenses/by-nc-sa/4.0/ or send a letter to Creative Commons, PO Box 1866, Mountain View, CA 94042, USA.

Published by:

\section{Centrul Național de Politici și Evaluare în Educație \\ UNITATEA DE CERCETARE ÎN EDUCAȚIE}

http://www.ise.ro/

https://rocnee.eu/

Further information about Revista de Pedagogie - Journal of Pedagogy can be found at:

Editorial Policy: http://revped.ise.ro/editorial-policy/

Author Guidelines: http://revped.ise.ro/the-writer-guide-2/ 


\title{
LOW QUALITY OF THE EDUCATIONAL PROCESS - MAIN CAUSE OF THE EARLY SCHOOL LEAVING
}

\author{
Technical University of Civil Engineering, \\ National Center for Policy and Evaluation in Education, \\ Education Research Unit, \\ Bucharest, Romania \\ adelataranu@gmail.com
}

Adela Mihaela ăranu*

\begin{abstract}
The association of three concepts - quality, equity, inclusion - represents the transversal axis of international and European educational policy documents nowadays, hence being an important aim for all education systems. According to the UNESCO strategic documents on education for the period up to 2030 and to the development objectives for this millennium, the creation of inclusive educational systems stands as the surest path to social inclusion. Inclusion is an aspect consistent with value and with the principle of equity, aimed at ensuring the right of all children to develop and reach their full potential. The European Commission defines equity as the extent to which individuals can benefit from and access educational opportunities, educational interventions and outcomes, along with those of professional education and training.

At an international level, the early school leaving indicator assesses the extent to which a given system manages to fight inequalities in terms of exclusion. According to the Eurostat 2019 data on Romania, at a level of $16.4 \%$ in 2018 , the early school leaving and training rate (for individuals aged 18 to 24) remains one of the highest rates in the EU. The percentage is significantly higher compared to the EU average and to the national target for 2020. The study argues that in spite of the policies for
\end{abstract}

* Associate profesor PhD, Technical University of Civil Engineering, Teacher Training Department, Bucharest, Romania.

Researcher, National Center for Policy and Evaluation in Education (NCPEE),

Education Research Unit, Bucharest, Romania. 
improving the quality of education over the past decade, most of the measures are focused on approaching the social barriers regarding the access to education, and less on increasing the quality of the education provided in schools (education as a process).

Keywords: early school leaving, educational policies, equity, inclusive education, quality education.

\section{Rezumat}

Asocierea a trei concepte - calitate, echitate, incluziune - reprezintă acum axa transversală a documentelor de politici educa ionale interna ionale şi europene, deci şi o intă importantă pentru toate sistemele de învă ământ. Potrivit documentelor strategice ale UNESCO referitoare la educa ie în perspectiva anului 2030 şi la obiectivele de dezvoltare pentru mileniul în curs, calea cea mai sigură pentru incluziunea socială o reprezintă crearea sistemelor educa ionale incluzive. Incluziunea reprezintă un aspect consecvent valorii şi principiului echită ii, menit să asigure dreptul tuturor copiilor de a se dezvolta şi de a-şi atinge întregul poten ial. Comisia Europeană defineşte echitatea drept gradul în care persoanele pot valorifica accesul şi oportunită ile educa ionale, interven iile şi rezultatele educa iei, respectiv ale formării profesionale.

La nivel interna ional, indicatorul ,early school leaving” înregistrează măsura în care un sistem reuşeşte să combată inechită ile în termeni de excluziune. Conform datelor Eurostat 2019 pentru România, la un nivel de 16,4\% în 2018, rata părăsirii timpurii a şcolii şi formării (de către persoanele între 18 şi 24 de ani) rămâne una dintre cele mai crescute din UE. Procentul este semnificativ ridicat comparativ cu media UE şi fa ă de inta na ională pentru 2020. Studiul sus ine că, în ciuda politicilor de îmbunătă ire a calită ii educa iei din ultimul deceniu, majoritatea măsurilor sunt axate pe abordarea barierelor sociale în calea participării şcolare şi mai pu in pe creşterea calită ii educa iei oferite în şcoli (calitatea de proces).

Cuvinte-cheie: calitatea educa iei, echitate, educa ie incluzivă, părăsirea timpurie a şcolii, politici educa ionale. 


\section{Three concepts, multiple challenges}

Quality, equity and inclusion are the three concepts aimed at fundamentally changing educational perspectives and practices. On the quality - quantity axis, our aim is to point out the dynamics of such concepts as school participation and inclusion. As it is characteristic to systems, satellite concepts gravitate at the intersection between values and actions, serving an important role in the assessment of the distance between declarative/ ideational and actuality/ practicality. Such a concept is the one of early school leaving, the key through which we will then look at the specific educational policies at the European level and at the level of the Romanian educational system as well. This analysis has the aim to underline, as much as possible, the evolutions, the snapshot realities and the effects that these concepts will have as they are identified in the field of literature. We think that a reflexive approach will be interesting for researchers, evaluation programme staff and teachers, which can observe the cleavages between practice and the theoretical conceptualisation and, as a result, they could adopt a creative approach on their practice.

\subsection{Quality education, between unification and conceptual problematisation}

The concept of quality education is a constant concern in terms of the education-focused type of discourse at international level, with a recent comeback through the increasingly sustained attempts at its operationalisation. Organisations such as UNESCO, the World Bank, OECD or the institutions of the European Union emphasise that high-quality education is a crucial matter in post-2015 educational agendas, correlated with the social and economic development objectives of the states. On the other hand, there is not any consensus on the conceptualisation of quality, as shown by a document of $\operatorname{UNESCO}(2005$, p. 1): 'There is no one definition, list of criteria, a definitive curriculum, or list of topics for a quality education. Quality education is a dynamic concept that changes and evolves with time and changes in the social, economic and environmental contexts of place'. Beyond the international discourse, with the movement for ensuring the quality of education, at the level of national systems the 
main challenge is the need of increasing the quality of education in terms of how to ensure high-quality education in a cost-effective manner.

A series of articles and summary reports on literature (Laurie et al., 2016) refer to several dominant models: (1) the economic model of education, based on the theory of human capital, refers to quantifiable inputs and outputs (measurable quantitative results); (2) the humanistic model, based on the theories of human development, regards education as a process at the centre of which are the pupils and students and it refers to broader personal and social objectives; (3) the model of contextualised learning/ education, based on the constructivist paradigm, proposes the integration of the relevant knowledge from the local level onto academic learning as a solution for ensuring the sustainability of the programmes.

Some authors recommend several unifying perspectives on quality, such as the framework for quality education designed by Nickel and Lowe (2010, p. 599) structured on seven dimensions of quality in education: effectiveness (the extent to which the declared educational objectives are accomplished), efficiency (the economic grounds of quality), equity (ensuring access and participation in education for all individuals), responsiveness (responding to the needs of every pupil taking their uniqueness into consideration), relevance (the utility of education for pupils both in the short and long term), reflexivity (the ability to adapt to change and uncertainty), and sustainability (a focus on behaviour change and the increase of responsibility at individual, local and global levels).

The mere reading of these dimensions shows that the sphere which the concept of quality aims to encompass is impossible to be described so that its complex reality can be analysed and improved. Hence, educational policies have encouraged educational systems to assume more liberty/ decentralisation in terms of choosing management models and assuming responsibility toward the actors involved. At the same time, stances of teachers and researchers were developed, according to which liberty and professional responsibility must be protected from the external assessment of the educational processes as a product of quality assurance procedures (Doherty, 2008). Conversely, an increasingly noticeable suggestion regards an orientation toward reflection on the practices/ the analysis of the micro- 
processes of teaching and learning and of quality work (Elken \& Stensaker, 2018). Moreover, a group of theorists and practitioners in the field of education influenced by the philosophy of Deleuze (Dahlberg, 2016; Moss, 2016) support the search for alternatives to quality, which they regard as counterproductive in relation to the social and educational objectives referring to diversity, participation, inclusion and innovation. The beyond quality movement advocates that the desire for quality, the language of quality, and the methods for quality continue to dominate throughout policy documents, academic studies, and the discourses of practitioners, oftentimes void of content and thus lacking the possibility of problematisation, which may entail great disservice for education (Moss, 2016, p. 132).

\subsection{Educational equity, beyond equality}

The concept of equity is very often invoked in relation to that of quality, even as a dimension of the quality of education, as mentioned above. Its discursive sphere comprises concepts such as social justice, solidarity, responsibility, tolerance, individual autonomy, exclusion / marginalisation. Whereas equity gradually became a common ground, there are heavily ideological discourses of deficit and drawbacks running in the background that come to insidiously stereotype the representations of teachers, the curricula and pedagogical practices (Webster \& Ryan, 2018).

The promotion of equity in education was introduced by the United Nations through key documents and the 2015 Incheon Declaration which reaffirmed the importance of equity for a renewed education agenda (UNESCO, 2015). The OECD also has a history of over 50 years advocating for the concepts of equality and equity, oriented in four directions: equity of access or equality of opportunity, equity in terms of learning environment or equality of means, equity in production or equality of achievement (of results), and equity in using the results of education (Levin, 2003). Also, the EU designed relevant documents on the matter of equity at the level of its member states, especially after the year 2000. In one of them, the EU defines equitable education systems as those that make sure that the results of education and training are independent from the socio-economic environment or from other factors leading to educational disadvantages, and that the educational interventions 
reflect the individuals' specific learning needs (CEC, 2006, p. 2).

As in the case of quality, there is no consensus on the conceptualisation of equity either. An extremely large amount of literature was written on the topic of equity in education, indicating, if we were to greatly simplify it, on the one hand the acknowledgement of the fact that there are groups struggling with significant obstacles in education (especially referring to women, ethnic minorities, disabled persons and socio-economically disadvantaged groups) and, on the other hand, expressing the intention of promoting education for all. Educational equity implies the adjustment of educational opportunities (including adaptation, varied resources and media) in order to respond to the needs of all and each, which are not the same/ equal. In contrast, equalityif it refers to equal chances, the equality of results or the equality of opportunity - implies the uniform distribution of resources and services, regardless of needs, hence regardless of individual and social circumstances (Levin, 2003, p. 9).

It is a known fact that school is not a neutral space and that individual data do not become barriers or opportunities in isolation, but only in interaction with others in the common space (of school), hence the idea that educational inequity is related to the inequality in the capacity of various groups to influence the structure of the curriculum, the essence of formal education (Webster \& Ryan, 2018, p. 127). The effectiveness of policies in the field depends on the knowledge of the phenomenon; hence, one of the challenges is the necessity to make inequity visible. The definitions of educational inequality usually operate with three criteria, as noted by the authors of a Report carried out by the USA on the matter of educational equity (Edley et al., 2019, p. 23): the existence of significant disparities among groups in matters of graduation or access to educational resources, reflected in educational results; the existence of a weak correlation between resources and pupils' needs; the inadequacy of the efforts for reducing educational segregation or the structural disadvantages of a group of pupils. The report supports the introduction of certain indicators for equity that would offer decision makers and the concerned parties the occasion '...to make their own judgments as to the importance of an observed disparity and what can be done to reduce it, considering other calls on political will and resources' (Edley et al., 2019, p. 23). 


\subsection{Inclusion and the challenge of diversity in education}

Inclusion represents an aspect consistent with value and the principle of equity and it refers to the ability to ensure the right of all children to develop and reach their full potential (UN, Convention on the Rights of the Child, 1990). Even those who deconstruct concepts such as quality and equity in education agree that inclusion is a concept of maximum relevance for education and that inclusive education proposes the most viable actionable solutions possible (Jones et al., 2016).

The effects related to discrimination and segregation represent a constant concern of the UN in matters of human rights, and the moment of the World Declaration on Education for All (Jomtien, 1990) and the one of the Salamanca Statement (1994) are regarded as benchmarks in the acknowledgement at a global level of the fact that inclusive education is 'an ongoing process aimed at offering quality education for all while respecting diversity and the different needs and abilities, characteristics and learning expectations of the students and communities, eliminating all forms of discrimination' (UNESCO, 2008, p. 3).

Inclusion is also a concept highly reliant on values, hence 'the current debate is no longer about what inclusion is and why it is needed; the key question is how it is to be achieved' (European Agency for Special Needs and Inclusive Education, 2014, p. 5). The literature (European Agency for Special Needs and Inclusive Education, 2018) and metastudies (Göransson \& Nilholm, 2014) on the empirical evidence observe the challenges of the implementation of inclusion caused by the variety of meanings of inclusive education within national practices, by the lack of coherence and consistency of policies, by large variations in the formation of the competencies of professionals, by inclusive pedagogies and resources, and by the yet inconclusive results of research data on the effects that inclusion has on the learning and development of pupils.

The inclusion of all children and the ensuring of educational progress for every pupil implies that change has to occur in all aspects - legislative, structural and institutional, in terms of mindset/ behaviour. Hence, the model of inclusion cannot be imported and the strategy of a given country for 
identifying its own perspective on inclusion has to take into consideration, according to analysts (Ainscow, 2016), the following elements: inclusion is a continuous process; inclusion is concerned with the identification and removal of barriers; inclusion refers to the presence, participation and achievement of all students; inclusion involves a particular emphasis on those groups of learners who may be at risk of marginalisation, exclusion or underachievement.

At the level of the European Union, the Report on the Implementation of ET 2020 - the Strategic Framework for European Cooperation in Education and Training proposes that inclusive education, equality, equity, nondiscrimination and the promotion of civic competences be placed among the priorities of European cooperation in the field of education and training (EU, 2015).

Despite several formal rulings in favour of inclusion, at national levels the tensions and disputes arising from the lack of coherence and from competing interests negatively affect their implementation (The European Agency for Special Needs and Inclusive Education, 2018). The studies have identified a strong correlation between national traditions and practices for inclusion, which means that it is very difficult for countries and schools to implement an advanced model of inclusive educational policies in a short timeframe.

\section{Educational exclusion and the phenomenon of early school leaving}

The extent to which a given educational system manages to combat inequities in terms of exclusion constantly refers to the early school leaving indicator. In accordance with international and European practice (Council Recommendation, 28.06.2011), early school leaving is defined to describe the situation of individuals aged 18-24 who leave the education and training system at the level of secondary education or before this level. According to the strategy aimed at reducing early school leaving in Romania, the category of young people who are not included in the education system hence consists of those who have concluded only the pre-school education, primary school or no more than two years of upper secondary education 
(ISCED - the International Standard Classification of Education), respectively those young people who completed a level of pre-vocational and vocation training which did not allow them to obtain a Capacity Certificate. Diminishing early school leaving is in line with both the ET 2020 objective of intelligent growth through the improvement of education and professional training levels, and with the objective of inclusive growth, through dealing with one of the most significant risk factors in terms of unemployment, poverty and social exclusion, with a reduction target at EU level set to less than $10 \%$ by the year 2020 .

To a larger extent than social interventions, a deep understanding of the phenomenon of participation in education and actions with a direct impact on the educational process stand as conditions for increasing quality and equity in the educational system (UNICEF-ISE, 2017).

\subsection{Educational exclusion and the excluded}

As in the case of inclusion, educational exclusion can be understood in a context broader than the usual one, referring to all the situations/ strains that may result in temporary, long-term or permanent exclusion (including the disciplinary type) or referring to full participation in education (caused by difficulties in interacting or by the feeling of not being valued by others, difficulties in understanding what is taught in school, etc.).

The concept of vulnerability is related to exclusion and it refers to individuals or groups who are more exposed to risk, who need specific support or benefits in order to compensate for health-related, economic or social drawbacks. In an extensive study on the conceptualisation of vulnerability (Virokannas et al., 2020), the authors bring to our attention several topics related to vulnerability and the critical comments on this concept which has become fashionable. According to them, the largest number of studies referred to the groups of population in situational vulnerability, among which the youth transitioning to adult life hold an important place, especially those who are likely to develop risk-increasing behaviours. Among them, naturally/ born vulnerable groups were identified on criteria especially relating to gender and disability. In general, we can distinguish among three fundamental areas 
that can result in the vulnerability of young people, a vulnerability that tends to unfold into a downward spiral (World Bank, 2005), so that with each shock, the child goes down further reaching a new level of vulnerability, and with each level he/ she is exposed to a host of new risks: material aspects shelter, food, clothing, money, medical care and education; emotional aspects - care, love, support and emotional control; social aspects - not belonging to a social group of equals, lack of role models to follow or guidance in difficult situations and risks in one's close environment. Based on data from the national longitudinal study on the youth in the US, Berzin (2010) aimed to identify the patterns in the development of the youth transitioning to adult life based on their level of education and social outcomes. His analysis shows that demographic characteristics, the main features of the growing environment at home and psychosocial resources can predict membership to risk groups; in this regard, involvement in youth-serving government systems is associated with poorer outcomes and remains salient when considered with other risk factors (Berzin, 2010).

Regarding the debatable aspects of operating with concepts such as vulnerable, excluded, marginal or at risk, we should recall the fact that these practices result in a delimitation between those inside and outside the norms of competence and success (Dahlberg, 2016, p. 128) and in differentiation procedures which can generate counterproductive classification and labelling such as the NEET (Not in Education, Employment or Training). Elina Virokannas et al. (2020) conclude that it is necessary to admit the temporal, situational, relational and structural nature of vulnerability, and that social research should be focused on vulnerabilityinducing life situations and on the role of social or educational services/ interventions in the reduction, but also in the accumulation or (re)production of vulnerability.

In accordance with this perspective, using the level of visibility of the data regarding children (visible/ invisible children), UNICEF designed a detailed framework for the categories of children and adolescents either excluded or at risk of exclusion. The UNICEF multidimensional model of exclusion makes the difference between the children/ adolescents who are not included in the education system and those at risk of early school leaving and distinguish among the children/ adolescents who are out of school as a result 
of early school leaving, the children/ adolescents who enrol late in school and the children/ adolescents who will never go to school (UNICEF, 2017, pp. 5-6).

\subsection{The slippery realities and the early school leaving policies}

As mentioned above, in accordance with international and European practice, early school leaving refers to adolescents and young people who leave the training and school system at the level of secondary education or before this level. The complementary concept of school dropout is one of the severe forms of non-participation in school and its estimation can be a relevant indicator for an in-depth understanding of the phenomenon of early school leaving, however, the methodological differences arising among states when it comes to its definition and calculation limit its relevance at an international level. Moreover, the impossibility of a realistic assessment on the phenomenon of school dropout, hence on combating it, is exacerbated by the non-harmonisation of the definitions with which each national system operates, as in the case of Romania (UNICEF-ISE, 2017).

Alternatively, one of the methods used is the analysis of school dropout cohort analysis, focused on a given generation throughout a full school cycle. This indicator calculated for Romania as well, with the support of UNICEF (UNICEF-ISE, 2017), offers a more accurate perspective on this phenomenon, allowing for a better substantiation of the set of existing data at the level of the system and educational policies.

A recent analysis (Tuparevska et al., 2019) carried out on the most important European policy decisions in the field of education, shows that most of the measures are aimed at early school leavers and they are offered a wide range of measures ranging from second chance schools and opportunities to high-quality early childhood education and care. Among those, the measure on the development of basic skills is one of the most invoked directions when referring to the low-skilled and early school leavers. The New Skills Agenda for Europe (EC, 2016, p. 5) suggests to 'where possible - develop a wider set of skills leading to an upper secondary education qualification', but it is again literacy, numeracy and digital skills that is on 
offer for vulnerable groups such as early school leavers and the low-skilled. A series of authors emphasizes that a focus on critical literacy (which allows one to read the world, i.e. Freire) will not only ensure the democratic skills for people which are so necessary to making these groups visible, but it will also make the discourse on basic skills less individualistic and competitive (Tuparevska et al., 2019). The same study notes that despite EU policies for reducing social exclusion, Eurostat data show that the statistical indicators of poverty and social exclusion (AROPE) have not significantly improved since the launch of Europe 2020. Hence there are certain groups that continue to face barriers when it comes to benefiting from the measures provided through various programmes or risk of being excluded from learning opportunities, such as the unemployed, Roma, the persons who live in rural or distant areas, disabled persons, single parents, the homeless, former criminals, accumulating the initial disadvantage and passing it from one generation to another.

\subsection{The approach of early school leaving in Romania}

Unlike individual data processing, i.e. beyond our personal or group experience (which could be either positive or negative), when it comes to decision making in a national education system, statistics is the one to set reality.

According to the Eurostat 2019 data, the early school leaving rate (for ages 18-24) in Romania, situated at 16.4\% in 2018 (down from 18.1\% in 2017), remains among the highest in the EU. Its value is significantly above the EU average (10.6\%) and above the national target for $2020(11.3 \%)$. In 2017, the participation of children aged between 4 and the mandatory school age of 6 slightly increased to $89.6 \%$, a value still under the $95 \%$ reference value of Education and Training 2020 (EC, Education and Training Monitor, 2018).

The Country Report Romania 2019 identifies the main realities leading to the poor educational performance: a low level of educational expenditure (among the lowest in the EU), especially when it comes to early childhood education, considered essential for preventing early school leaving, a low 
level of engagement in the system of childhood care and education (also due to lack of facilities); challenges regarding the development of basic and digital skills; a weak correlation between the school network and demographic tendencies; the insufficient development of teachers' competencies to apply an approach that is focused on the pupil; the persistence of rural-urban disparities; limited access to quality education for vulnerable groups, especially for disabled persons and Roma. The data shows limited government financial commitment to education (3.7\% of the GDP in 2017, compared to the EU average of $4.7 \%$, Eurostat, 2019); in 2016, the level of educational expenditure of public and private educational institutions for each pupil / student was of approximately 2,074 EUR, compared to the EU average of 6,869 EUR. When it comes to infrastructural and institutional development, Romania drafted a strategy for the modernisation of educational infrastructure (2018-2023) in order to approach significant efficiency-related and equityrelated challenges: $10 \%$ of schools are overcrowded (especially in urban areas), whereas $60 \%$ are underused (especially in rural areas); school transportation services are generally insufficient and inadequate, whereas accessibility worsens as pupils go through the school system.

When it comes to participation, significant disparities at ethnic (especially for Roma) and territorial (especially in rural areas) levels are mentioned. Whereas $95 \%$ of children aged 7-14 are enrolled in primary and secondary education, this is true for only $77 \%$ of Roma children, and only $34 \%$ of Roma children aged 15-18 participated in secondary higher education (FRA, 2016).

According to the 2018 Education and Training Monitor, Romanians are significantly behind the EU average when it comes to the basic skills that predict the continuation and completion of studies. Although Romania's PISA scores improved starting with 2006 and dropped in 2018 in comparison to the ones in 2015, they still remain significantly lower than those of other states in the EU. The implementation of the competence-based curriculum is in progress and it has encountered difficulties. In addition, teachers' skills of practicing a student-centered pedagogy are insufficiently focused on the challenges in the classroom, including on the support of children with learning deficiencies or of children at dropout risk (ISE, 2018). 
Based on the European Union's (EU) jobs and growth strategy for 2010-20 (EU 2020), Romania has developed five national strategies in the field of education, focused on the great challenges for the Romanian education system: reducing early school leaving (2015-2020), improving the quality of tertiary education (2015-2020) and the VET(2016-2020), the promotion of lifelong learning (2015-2020) and investments in the infrastructure of educational institutions (2018-2023).

To approach the critical topics mentioned above, the National strategy for the reduction of early school leaving 2015-2020 highlighted the importance of the early childhood years in child development and school readiness, as a prerequisite for success in school and it focused on the concept of integrated response in terms of policies and services from all relevant fields (education, healthcare, social protection, etc.), with the horizontal and vertical coordination between the relevant public and private actors. The programmes proposed in this pillar refer to the increasing of enrolment rates in early childhood education, primary and secondary lower education. In the context of the expansion of participation in education, it proposes granting special attention to the progressive expansion of preschool education (ages 3-5) in order to obtain a universal enrolment rate. Additional results on enrolment in the primary and secondary inferior cycles are also proposed for approaching disparities in learning outcomes among the various target groups of children aged 11 to 17, especially for those in precarious economic environments from rural areas, Roma children and other minority groups through: developing systems for early detection and intervention; the consolidation, expansion and personalisation of counselling services and the introduction of promotion mechanisms for educational student-centered programmes, as well as of other types of programmes for keeping pupils in the system.

A series of other additional strategies has been developed. The Strategy on poverty reduction and social inclusion 2016-2020 renders explicit the main government objective of insuring equality of opportunities for the promotion of quality education for all, paying special attention to the quality of education and professional training and to their relevance for both the necessities of the labour market and those of individuals. It also aims at improving teachers' abilities to efficiently provide an inclusive education 
to Roma children and to eliminate the segregation, discrimination and negative stereotyping of Roma children in schools. Increasing the access of children from marginalised areas represents another critical topic calling for: the improvement of facilities, qualified teachers, educational materials and modern equipment. Also, according to the National Youth Strategy 2015-2020 the objectives specific to the education pillar refer to ensuring access to education and a quality formal and non-formal education for all the youth and adolescents; the improvement of the non-formal education options; ensuring a practical relevance for the competencies acquired through formal and non-formal education.

When we refer to outcomes, a relevant fact may be that in the year 2017 less than a quarter of the allocated budget was spent for the four educational strategies. Along with financial limitations, delayed decision making and their implementation, as well as the discrepancies in the changes recorded for the rural area and the urban area (the case of early school leaving) limit the development of these strategies.

\section{Discussions}

As we have seen above, the period after the years 2014/2015 meant an accentuation of equity-related aspects in EU policies, especially the measures on reducing early school leaving, a fact that also echoed in national policies, as in the case of Romania. On the other hand, the EU and OECD statistics, in spite of their many errors and reporting ambiguities, serve the main role of adjusting policies at national levels, identifying the action areas and lending them legitimacy. Some authors talk about a transition of educational systems toward Europeanisation (Alexiadou et al., 2019), through which the groups of disadvantaged youngsters, such as Roma, now have a chance to not become lost because of legislation and policies.

The discussion in our study of the three initial concepts - quality, equity, inclusion - revealed that a large part of international institutions, school and government-level decision makers, researchers and practitioners consider that participation in school until the tertiary level represents a clear measure of / result of quality and equitable education and a guarantee for 
social and personal success. This simplistic view on the educational path and transitions from a period of schooling to another or to the labour market has been the basis for the policies and programmes. We also saw that the problematisation by specialists and practitioners regarding the various aspects of designing and experiencing these educational transitions, reflect their processual nature and the necessity of an integrated approach (at the intersection of education, healthcare, social and labour policies).

In Romania, the situation of those who leave/ do not participate in school is 'traditionally' tolerated as a normal loss in school selection/ evolution. This rhetoric is less likely to change in the near future, in the context of conceptualisations that leave room for defining the problematic aspects of education in stigma terms, with rather socially oriented solutions. The UNICEF-ISE study (2017) suggests that the measures that reached the disadvantaged groups (from a territorial, economic and ethnic perspective) were rather focused on approaching the social barriers to participation in school and the high rate of early school leaving is likely to persist. It mentions that despite the policies for improving the quality of education in this past decade, among which the designing of a new curriculum, the promotion of measures for an internal assurance of the quality of school, investments in school/ educational infrastructure or the implementation of in-service learning programs for teachers and school management, the interventions were not sufficiently correlated.

In this complex and contradictory space, in the context of the discursive avalanche and of the pressure of the policies directly mandating schools to address issues of diversity, inclusion and equity, teachers stand as the most important variable of schools when it comes to the valuing of inter-individual differences, with clear effects on the outcomes (Ewing, 2013, as cited in Webster \& Ryan, 2018).

A study on unexcused school absenteeism carried out in a community in Sweden (Ekstrand, 2015) highlighted that the pupils who are absent from school usually experience and regard school work and education as lacking in meaning, in challenges, and they react to this by contesting or ignoring it. The positive approach on school culture and of pedagogy, highlighting the strengths (and not the weaknesses) is a process implying the need for change 
at all levels - of the government, the community, the school organisation and among the personnel. The success in Romania of the program A second chance addressed to those who resume their studies after having dropped out or to those who have never been enrolled in school confirms the theses according to which pupils need adults to take care of them, respect them and involve them both socially and educationally. On the other hand, ensuring basic skills represents a necessary condition for learning, but it is also necessary to add the ability of self-reflection and decision-making which, along with self-esteem, creates the feeling of being capable of tackling schoolwork, and even the capacity to resume going to school (Ekstrand, 2015).

\section{References}

- Ainscow, M. (2016). Diversity and Equity: A Global Education Challenge. New Zealand Journal of Educational Studies, 51, 143-155.

https://doi.org/10.1007/s40841-016-0056-x

- Alexiadou, N., Helgøy, I., \& Homme, A. (2019). Lost in transition - policies to reduce early school leaving and encourage further studying in Europe. Comparative Education, 55(3), 297-307.

https://doi.org/10.1080/03050068.2019.1619327

- Berzin, S. (2010). Vulnerability in the transition to adulthood: Defining risk based on youth profiles. Children and Youth Services Review, 32(4), 487-495.

https://doi.org/10.1016/j.childyouth.2009.11.001

- Commission of the European Communities (CEC). (2006). Efficiency and equity in European education and training systems (COM(2006) 481 final). Commission of the European Communities.

- Council of the European Union. (2011). Recomandarea Consiliului din 28 iunie 2011 privind politicile de reducere a părăsirii timpurii a şcolii. https://eur-lex.europa.eu/legal-content/RO/TXT/PDF/?uri= CELEX:32011H0701(01)\&from=EN

- Dahlberg, G. (2016). An ethico-aesthetic paradigm as an alternative discourse to the quality assurance discourse. Contemporary Issues in Early Childhood, 17(1), 124-133. https://doi.org/10.1177/1463949115627910

- Doherty, G. (2008). On quality in education.Quality Assurance in Education, 16(3), 255-265. https://doi.org/10.1108/09684880810886268

- Edley, C., Koenig, J., Nielsen, N., \& Citro, C. (Eds.). (2019). Monitoring Educational Equity. National Academies Press. https://doi.org/10.17226/25389

- Ekstrand, B. (2015). What it takes to keep children in school: a research review. Educational Review, 67(4), 459-482. 
https://doi.org/10.1080/00131911.2015.1008406

- Elken, M., \& Stensaker, B. (2018). Conceptualising quality work in higher education. Quality in Higher Education, 24(3), 189-202. https://doi.org/10.1080/13538322.2018.1554782

- EU. (2015). Joint Report of the Council and the Commission on the implementation of the strategic framework for European cooperation in education and training (ET 2020) - New priorities for European cooperation in education and training.

https://eur-lex.europa.eu/legal-content/EN/ALL/?uri=CELEX\% 3A52015XG1215\%2802\%29

- European Commission/Eurydice România. (n.d.). Reforme în derulare şi evolu ii in materie de politici. https://eacea.ec.europa.eu/national-policies/eurydice/ content/ongoing-reforms-and-policy-developments-56_ro

- European Agency for Special Needs and Inclusive Education. (2014). Five Key Messages for Inclusive Education. Putting Theory into Practice.

https://www.european-agency.org/sites/default/files/Five\%20Key\% 20Messages\%20for\%20Inclusive\%20Education.pdf

- European Agency for Special Needs and Inclusive Education. (2018). Supporting Inclusive School Leadership: Literature Review.

https://www.european-agency.org/sites/default/files/SISL_Literature_Review.pdf

- European Commission. (2016). The new Skills Agenda for Europe. https://ec.europa.eu/social/main.jsp?catId=1223

- European Commission. (2018). Education and Training Monitor 2018, Country analysis: Romania. https://ec.europa.eu/education/sites/education/files/ document-library-docs/volume-2-2018-education-and-training-monitor-countryanalysis.pdf

- European Commission. (2019). Country Report Romania 2019 Including an In-Depth Review on the prevention and correction of macroeconomic imbalances. https://ec.europa.eu/info/sites/info/files/file_import/2019-europeansemester-country-report-romania_ro.pdf

- European Union Agency for Fundamental Rights (FRA). (2016). Second European Union Minorities and Discrimination Survey (EU-MIDIS II) Roma Selected findings. https://fra.europa.eu/sites/default/files/fra_uploads/fra-2016eu-minorities-survey-roma-selected-findings_ro.pdf

- Eurostat. (2019). Eurostat 2019 data. https://ec.europa.eu/eurostat/data/database; https://ec.europa.eu/eurostat/statistics-explained/images/e/e7/Total_general_ government_expenditure_on_education\%2C_2017_\%28\%25_of_GDP\%29.png

- Göransson, K., \& Nilholm, C. (2014). Conceptual Diversities and Empirical Shortcomings - ACritical Analysis of Research on Inclusive Education. European Journal of Special Needs Education, 29(3), 265-280.

https://doi.org/10.1080/08856257.2014.933545 
- Institutul de Ştiin e ale Educa iei (ISE). (2018). Raport privind nevoile de formare ale cadrelor didactice din învă ământul primar şi gimnazial.

https://www.educred.ro/noutati/nevoile-cadrelor-didactice-pentru-formarea-indomeniul-abilitarii-curriculare/

- Jones, L., Osgood, J., Holmes, R., \& Urban, M. (2016). Reimagining quality in early childhood. Contemporary Issues in Early Childhood, 17(1), 3-7. https://doi.org/10.1177/1463949115627912

- Laurie, R., Nonoyama-Tarumi, Y., Mckeown, R., \& Hopkins, C. (2016). Contributions of Education for Sustainable Development (ESD) to Quality Education: A Synthesis of Research. Journal of Education for Sustainable Development, 10(2), 226-242. https://doi.org/10.1177/0973408216661442

- Levin, B. (2003). Approaches to Equity in Policy for Lifelong Learning. Equity in Education.

http://www.oecd.org/education/innovation-education/38692676.pdf

- Moss, P. (2016). Why can't we get beyond quality? Contemporary Issues in Early Childhood, 17(1), 8-15. https://doi.org/10.1177/1463949115627895

- Nikel, J., \& Lowe, J. (2010). Talking of fabric: a multi dimensional model of quality in education. Compare: A Journal of Comparative and International Education, 40(5), 589-605. https://doi.org/10.1080/03057920902909477

- PISA. (2019). Rezultatele elevilor din România la evaluarea interna ională PISA 2018. https://www.edu.ro/rezultatele-elevilor-din-rom\%C3\%A2nia-laevaluarea-interna\%C8\%9Bional\%C4\%83-pisa-2018

- Tuparevska, E., Santibáñez, R., \& Solabarrieta, J. (2019). Equity and social exclusion measures in EU lifelong learning policies. International Journal of Lifelong Education, 39(1), 5-17.

https://doi.org/10.1080/02601370.2019.1689435

- Virokannas, E., Liuski, S., \& Kuronen, M. (2020). The contested concept of vulnerability - a literature review. European Journal of Social Work, 23(2), 327-339. https://doi.org/10.1080/13691457.2018.1508001

- Webster, S., \& Ryan, A. (2018). Equity and (critical) diversity. In S. Webster \& A. Ryan (Eds.), Understanding Curriculum: The Australian Context (pp.126-143). Cambridge University Press.

- UNESCO. (2005). Contributing to a more sustainable future: quality education, life skills and education for sustainable development.

https://unesdoc.unesco.org/ark:/48223/pf0000141019

- UNESCO. (2008). Inclusive education: the way of the future. Conclusions and recommendations of the 48th session of the international conference on education (ICE). Geneva.

http://www.ibe.unesco.org/fileadmin/user_upload/Policy_Dialogue/48th_ICE/ CONFINTED_48-5_Conclusions_english.pdf 
- UNESCO. (2015). Education 2030: Towards inclusive and equitable quality education and lifelong learning for all. Paris.

https://unesdoc.unesco.org/ark:/48223/pf0000233029/PDF/233029eng.pdf.multi

- UNICEF - ISE. (2017). La şcoală. O privire asupra participării la educa ie folosind analiza pe cohortă. Editura Alpha MDN. http://www.unicef.ro/wp-content/uploads/Studiu-Cohorta.pdf

- UNICEF. (2017). Cadrul de monitorizare al copiilor afla i în afara sistemului de educa ie. Monitorizarea copiilor afla i în afara sistemului de educa ie şi a copiilor cu risc de abandon şcolar din România. http://www.unicef.ro/wpcontent/uploads/Cadru-de-monitorizare-a-copiilor-aflati-in-afara-sistemului-deeducatie-Romania_2017.pdf

- World Bank. (2005). Children \& Youth. A Resurse Guide. http://siteresources.worldbank.org/INTCY/Resources/ResourceGuide.pdf

The online version of this article can be found at: http://revped.ise.ro/category/2020-en/

\section{(c) EY-NG-SA}

This work is licensed under the Creative Commons Attribution-NonCommercial-ShareAlike 4.0 International License.

To view a copy of this license, visit http://creativecommons.org/licenses/by-nc-sa/4.0/ or send a letter to Creative Commons, PO Box 1866, Mountain View, CA 94042, USA.
Versiunea online a acestui articol poate fi găsită la: http://revped.ise.ro/category/2020-ro/

\section{$(c c)$ BY-NG-SA}

Această lucrare este licen iată sub Creative Commons Attribution-NonCommercial-ShareAlike 4.0 International License.

Pentru a vedea o copie a acestei licen e, vizita $i$ http://creativecommons.org/licenses/by-nc-sa/4.0/ sau trimite i o scrisoare către Creative Commons, PO Box 1866, Mountain View, CA 94042, SUA. 